\title{
The Role of Rural Women's Vocational Skills Training in Improving Their Entrepreneurial and Employability
}

\author{
Abelaka Icssrnerc \\ Associate Professor, Department of Education, Kumar Bhaskar Varma Sanskrit \& Ancient Studies University, Namati, Nalbari \\ PiN - 781337
}

icssrnercjournal@gmail.com

N. B. The findings of the study is from original field work and has not been submitted for publish elsewhere.

\begin{abstract}
The fast changing postmodern societies demand people acquiring new knowledge, skills and training for better living. Lifelong learning aims to fill the gap between existing knowledge in a person and the one required to enable one to act meaning fully when the changing situation demands. As per census 2011, more than $70 \%$ of the rural female workforce is engaged in agriculture in principal subsidiary capacity are around 75\% (NSSO, 2011) which are characterized by low earning, low productivity, poor working condition and lack of social protection. One of the key strategies of NMEW, 2010 in India is investment in skill and entrepreneurship development, micro credit, vocational training and SHG for economic empowerment of women. As the formal education sector is not enough for fulfilling the emerging needs of the rural women, it become imperative to provide lifelong skill training for empowering them. To know the relevance of life long skill learning in the area of Baihata Chariali, an effort was made to study the status of rural women who have undergone skill training under 'PMKVY', (Prime Minister Kaushal Vikash Yojana'), but could not involve themselves in income generating activities for different reasons. In this study, an attempt is made to know the functioning of training providers, placement trend and follow up mechanism and the required skill gap in terms of life long skill learning framework. The objective of the paper is to know the challenges in employment generation after having training, relevance of lifelong skill training and to suggest means for providing lifelong skill training for empowering the rural women.
\end{abstract}

Keywords: Life Long Skill Learning, Empowering Rural Women, Pradhan Mantri Kaushal Vikash Yojana

\section{Introduction}

"NO QUALITY LEARNING EVER GOES TO WASTE". One of the important indicators of women empowerment is to have economic independence that can be achieved through skill development. Skill development of rural women often requires combination of training in formal, non - formal and informal settings that comprise basic education, vocational training, life skill training, entrepreneurship training and agricultural extension service. As per census 2011, more than $70 \%$ of the rural female workforce is engaged in agriculture in principal subsidiary capacity are around $75 \%$ (NSSO, 2011) which are characterized by low earning, low productivity, poor working condition and lack of social protection. One of the key strategies of NMEW, 2010 in India is investment in skill and entrepreneurship development, micro credit, vocational training and SHG for economic empowerment of women. Under four separate schemes, the Assam Skill Development Mission (ASDM) has so far trained 77, 311 youths of which 43,770 have been placed. The youths are trained through 193 training partners in 761 centres across 35 sectors and 179 job roles. As the formal education sector is not enough for fulfilling the emerging needs of the rural women, it become imperative to provide lifelong skill training for empowering them. To know the relevance of life long skill learning in the area of Baihata Chariali, an effort was made to study the status of rural women who have undergone skill training under 'PMKVY', (Prime Minister Kaushal Vikash Yojana'), but could not involve themselves in income generating activities for different reasons. PMKVY is a path breaking initiative to mitigate the discrepancy among education, employability and productivity under which more than 70 skill development programmes are running throughout the country. As the scheme aligns itself to the common norms and partner payment is linked with placement, it is important to place at least $50 \%$ of the batch under PMVKY to ensure that its performance is up to the mark. There are 2150 training centre in India under PMVKY of which 43 are in Assam. Youths have been trained, assessed and certified in a specific job role and have ended up in a completely different job. Training is not aligned with demand, means trained skill is not demanded. Many youths trained and placed but leave in short time, because of high cost of living in the placed area. Because, training is provided on the ground of students accessibility. Placed students are many times unable to migrate. In absence of proper checking, training providers may franchise the entire training leading to substandard training that can lead to excessive assessment fraud. Besides, Public mobilization is more focused on youth aspiration than on fundamental equipment, leading to providing training to inappropriate applicants. It is reported that there is no process and system rationalization and the training has limited focus on outcome. Limited emphasis is placed on mapping the skilled workers needed across industries. Limited effort is made on placement and sustenance of such placement mechanism at grassroots level. Therefore, in this study, an attempt is made know the functioning of training providers, placement trend and follow up mechanism and the required skill gap in terms of life long skill learning framework. The objective of the paper is to know the challenges in employment generation after having training, 
relevance of lifelong skill training and to suggest means for providing lifelong skill training for empowering the rural women.

\section{Women Empowerment}

Women empowerment means giving power to women so that they may flourish with full potentialities to take decisions on their own and build capacities for their individual as well as national development. It is the expansion of resources, capabilities, choices and decisions, to participate, to negotiate, influence, control and hold offices that influence one's life positively.

\section{Lifelong Skill Learning}

The concept of life long skill learning emerged as a social movement in response to changing social demands like knowledge societies and knowledge economy. The purpose of life long skill learning is to facilitate transformation of a person cognitively, emotionally and practically by arming an individual with relevant skill throughout life. The fast changing postmodern societies demand people acquiring new knowledge, skills and training for better living. Lifelong learning aims to fill the gap between existing knowledge in a person and the one required to enable one to act meaning fully when the changing situation demands. Lifelong skill training is a solution to many problems of life specially when there is a setback in one's personal or professional life, it gives a new path to walk. The aim of such learning is to create a culture of learning to promote social and economic regeneration. Lifelong skill learning has successfully been implemented in different developing countries like Sri Lanka, Peru, Brazil etc for skill development and training programme for unskilled and semi - skilled person. In India, the programme may focus on motivating individual learners for learning through guidance services, outreach strategies, awareness raising campaigns, validation of non - formal and informal learning, developing appropriate approaches in partnership with NGOs. Using ICT, E - learning and the media to widen access, developing alternative learning approaches.

\section{Skill Development and PMVKY}

Skill India is a campaign launched by Prime Minister Narendra Modi on 15 th July 2015 which aims to train over 1 core people of India in different skills by 2022. It includes various initiatives of Govt. of India like, 'National Skill Development Mission, 'National Policy for Skill Development and Entrepreneurship 2015", "Pradhan Mantri Kaushal Vikash Yojana, Skill Loan Scheme. PMKVY is the flagship scheme of the Ministry of Skill Development and Entrepreneurship. Individuals with prior learning experience are also assessed and certified under Recognition of Prior Learning (RPL). Under the scheme, training and assessment fees are completely paid by the Government. Indian Nationality who is unemployed, school or college dropout may enrolled for it as identified the Sector Skill Council for their respective job roles.

For conducting the proposed study, three training centre in and around Baihata Chariali area are selected where training on different skills are provided and attempted to know the status of present training provision along with placement status. Besides, effort was also made to identify the women who have been offered job placement but unable to either accept or sustain themselves in the jobs. Along with this, a framework of providing life skill training is also tried to present through the paper. It is expected that the findings of the study will highlight the emerging issues related to proper implementation of skill development programme.

\section{Objectives of the Study -}

a) To examine the status of selected skill training centres under PMKVY of Baihata Chariali area.

b) To identify the reasons of non - engagement in economic activities of skilled women trainee.

c) To forward a suggestive framework of lifelong skill training for women

\section{Need and Significance of the Study -}

Data shows that females are engaged in agriculture and allied sectors, but there is hardly any special training for enhancing these skills. While $7.5 \%$ of them are engaged in household manufacturing sectors, most of the related training programmes hardly see any female participation. Therefore, opportunities must be created to enable women to acquire the skills necessary for entering those newly emerging occupations. From observation, it is found that though selected trained youths are offered job placement, some of them, especially women are sometimes neither in a position to accept the offer, nor sustain the profession due to different reasons that intensifies their level of frustration. It is felt that identification of the problems of rural women behind non engagement in economic activities after getting training and also placement offer will help other ways to identify the issues, sorting out of which will help in effective implementation of PMVKY in rural areas.

\section{Review of Related Literature}

Kanchan and Varshney (2015) observed that $80 \%$ of rural and urban Indian workforce has low marketable skills and various skill development initiatives result in skilled manpower to meet global need. Divyaranjaniand Rajasekar (2017) remarked on the importance of training and development efforts as training improves skills, capability, ability and finally worker performance and productivity. Patnaik et al (2018) observed significant role played by of ITes in achieving the goal of PMKVY. Agarwal M \& Thakur S. K (2019) reported improved productivity of the respondents after skill training. However, study on the job placement through PMKVY and its sustenance is not available. Therefore, it is expected that the findings from the study will be significant in effective policy implementation.

- Methodology of the Study - The present study is empirical in nature and descriptive Survey method is used in the study.

- Sample of the Study - Three training centres of Baihata Chariali area were purposively selected for the study from which 30 women are selected who have completed skilled training but unable to engage themselves in economically productive work.

- Nature of Data - Both primary and secondary sources were used for collection of data. 
- Tools Used -A self - prepared Interview Schedule is used to collect data from a sample of 30 rural women selected purposively who have undergone skill training.

- Delimitation of the Study: keeping in view the time and resource constraint the study is limited to the selected centres only.

\section{Analysis and Interpretation of Data}

Collected information of the study are analysed and presented in the following -

Objective No 1 - Status of skill training centres under PMVKY of Baihata Chariali area.

Table 1

\begin{tabular}{|c|c|c|c|c|c|}
\hline Name of the institute & Course offered & No of students & No of teachers & $\begin{array}{c}\text { Job/ Worker } \\
\text { Placement }\end{array}$ & Offer accepted \\
\hline \multirow{2}{*}{ Needs Technical Institute } & Electronics & 40 & 4 & \multirow{2}{*}{$20 / 12$} & \multirow{2}{*}{08} \\
\hline & Logistic Service & 60 & 4 & & \\
\hline \multirow{2}{*}{ Digital SRD Foundation } & Field Technicians and Storage & 120 & 6 & \multirow{2}{*}{$20 / 16$} & \multirow{2}{*}{04} \\
\hline & apparel & 120 & & & \\
\hline Subham Society & Electronic Courier Service & $\begin{array}{c}50 \\
50 \\
440\end{array}$ & $\begin{array}{l}4 \\
4\end{array}$ & $10 / 10$ & 0 \\
\hline
\end{tabular}

From the table -1 it has been observed that digital SRD Foundation have a sufficient number of students. Electronics, Field technicians and Logistic service are offered in the centres. The number of youths offered placement were found to be 20 in NEEDS out of which 8 have accepted the offer, in Digital SRD it is 20 where only 4 have engaged in job and in Subham Society 10 have got placement offer, but no one have joined in the vocation, in the year 2018 - 19. Though it is targeted to giving job offer to $50 \%$ of total qualified trainees, the rate of placement is not found satisfactory. The training programmes of these skill training centres follows the instructions of NSQFs and after completion of training and interview illegible youths are offered jobs under "Make in India Yojana" and "Digital India Project". The courses offered in these centres are of different duration i. e. 6 months, 1 year etc. the trainees have to the trainees. The infrastructure facilities of training centres are reported satisfactory by the trainees. Though the exact number is not available, some female trainees are reported of withdrawing themselves from completing the course.

Objective No 2 - Reasons of non - involving in economically productive work -

Along with the training and placement status of training centres, effort was made to know the causes or challenges in engaging oneself in economically productive work after having course completion certificate and also having job offers. For this purpose, 30 selected young women were interviewed who have course completion certificates and also got job offers. The reason behind their non - acceptance of job offers or inability to engage themselves in economically productive work are presented below in the table -2 .

Causes of Non - involvement in income generating work after having job offers after course completion -

\begin{tabular}{|c|c|c|}
\hline S. N. & Causes of Non - involvement in income generating work & $\begin{array}{c}\text { No of Trainees } \\
(\mathrm{N}=30)\end{array}$ \\
\hline 1 & Due to Fear, hesitation, anxiety, social pressure & 14 \\
\hline 2 & Lack of Motivation & 16 \\
\hline 3 & Lack of Social Security & 19 \\
\hline 4 & Distance (Long) from home & 8 \\
\hline 5 & Responsibility of home & 21 \\
\hline 6 & Low Salary & 12 \\
\hline 7 & Lack of cooperation from family & 17 \\
\hline 8 & Lack of confidence in English communication & 11 \\
\hline 9 & Lack of confidence in Risk taking & 08 \\
\hline 10 & Limited knowledge about finance and entrepreneurship \\
\hline
\end{tabular}

From table -2 , it has been observed that, most of the trainees have more or less similar problems that are mostly behavioural and situational. Low salary is one of the major issues of non - accepting the job offers, responsibility of home is reported as one of the problem of non - involving in income generating work.

\section{Portray of Lifelong skill learning for Empowerment of Rural Women.}

From the above discussion it has been observed that most of the rural women face similar problems that are mostly based on one's attitude, self - confidence and some are situational. Lifelong skill learning that may have after completion of formal skill training. It is a process through which additional know how is gained and improvisation of skills continues to occur throughout the time. A lifelong skill learning framework is attempted to present below - 


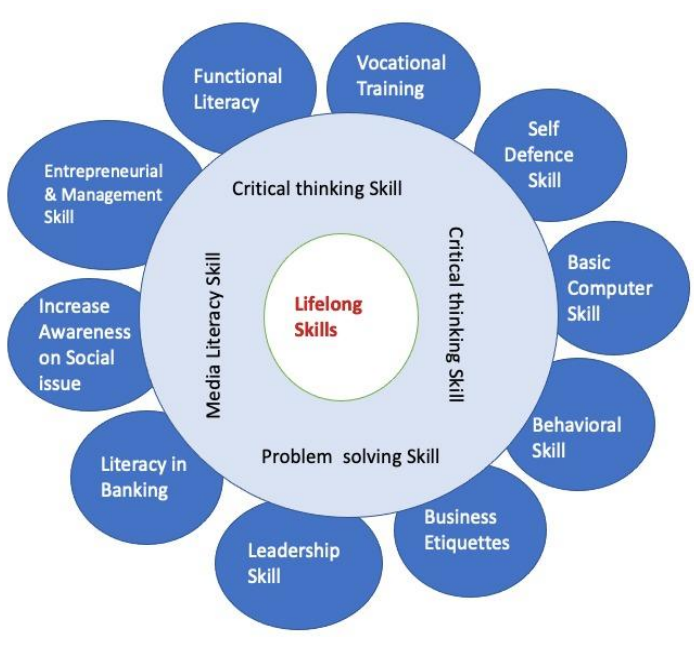

Potential areas of lifelong skill learning

Skill development of rural women requires a combination of training in formal and organized setting like educational and training institutions. In non - formal settings, different community groups, voluntary organizations can be involved in such venture. Peer groups, family members, media, online platforms, $\mathrm{T} \mathrm{V}$ programmes may also play crucial role in imparting lifelong skill training to women in an informal setting. Though different factors may come on the way of providing Lifelong skill training to women. Negative attitude of parents and society, family responsibility, limited access to land and other productive resources, narrow range of female dominated field of skill training, gender issues, lack of basic amenities and safety, lack of financial support to women entrepreneur, low payment are some of the issues that pushes back the from being self - sufficient.

Suggestions for effective implementation of skill learning For making the women power empowered, effective lifelong skill training is a must that need to provide to the women by expanding women's vocational education/ training programmes. Training on basic skills need to imparted on the basis of preliminary survey of skills need and aptitude of the learner. To attract more efficient women for training, avenues to access information about the skills and related schemes of training require awareness. Identification of employable sector and elimination of gender stereotyping are also equally important. Private sectors also need to come forward in such venture of imparting lifelong skill training to the women. Provision of community based training, raising awareness and motivation, setting up lifelong skill training centres in remote areas, involving NGOs and self help groups, easy processing of less expensive credit systems, formulating gender friendly policies developing system of security will definitely help the women to lead a life of respect, dignity and then only we can make our country a 'knowledge hub'.

\section{Major Findings of the Study}

- Skills training in different hands on skills have been provided by recognized training centres under Prime Minister Kaushal Vikash Yojana in Baihata Chariali area.
- Though varieties of subjects are not offered by the training institute, infrastructural facilities are satisfactory.

- Most of the respondents express satisfaction on the quality of training provided.

- Some students do not complete the full course due to hesitation, lack of motivation.

- Job placement is offered to few, but that too do not attract the trainees to accept due to varied reasons.

- Changing mind - set towards problems and behavioural training along with other skills through life long skill learning may enhance persistence among trainees for sustained employment avenues.

\section{Educational Implication}

Learning is a lifelong activity for a simple reason that it engages the mind in healthy pursuits like learning new skills, being part of a team, or an interaction with an expert who can guide an individual in right direction. The skill training centres align it to the common norms and part of a training partner which is linked with is linked to the placement. Unless the trainees are motivated enough to sustain with the scheme, these training provider entrepreneurs are also going to face challenge who have invest their hard earned money in the projects. The training provider should mobilize the applicant and pre - assess to absorb the course and enhance the skill for which the training is provided. Therefore, all the stake holders, Govt. policy maker, training provider, trainees' guardians need to ponder over the issue and take initiative to promote lifelong skills training. There is also need to take measures to promote investment to create employment opportunities as the youth faces problems of retention in employment outside their regions or state.

\section{Conclusion}

Skilled India Mission aimed to reach out to 300 million youths by 2022 , but by the end of 2018 , only 25 million had been reached and trained under scheme. Even under PMKVY, only $15 \%$ of the enrolled students were able to get a job. To bring expected outcome of the initiatives, capacity building among the staffs, trainers, efficient use of budgetary allocation, mapping of the linkage between demands of industry and skill courses are necessary. Most importantly, women cannot make themselves empowered by statutory provisions only, one need to empower one's self first. Lifelong skills learning emphasized on attitudinal and behavioural change. Most of the time, due to different reasons, affectivity of any Government schemes are not realized in its true spirit. It is imperative now; women should broaden their mental horizon, give look to opportunities and be confident to go ahead equipping one with these lifelong skills. It gives a new path, which could be a way forward to a brighter future for them and the nation as well.

\section{References}

[1] Agarwal M \& Thakur K. S "Impact of Pradhan Mantri Kaushal Vikas Yojana on the Productivity of Youth in Gwalior Region, India” in International Journal of Recent Technology and Engineering (IJRTE) Vol - 8, Issue - 4, Nov 2019. 
[2] Islam Nijairul (2019) "Empowerment of Women through life skill Learning" in University News, 57 (02) January, 2019.

[3] Jarvis, P (2006) "Globalisation, lifelong learning and learning society: Sociological Perspective., London Routledge.

[4] Kedar, P M (2015) Skill Development in India, Challenges and Opportunities, International Research Journal of Multidisciplinary Studies.

[5] Patnaik M. C B, Satpathy I Suhagi 'Role of ITes in Pradhan Mantri Kaushal Vikash Yojana (PMKVY): A Conceptual Study. International Journal of Mechanical Engineering and Technology 9 (8), pp 907 - 914.

[6] https: //www.mapsofindia. com

[7] Pmkvyofficial. org

[8] Process Manual for Prahan Mantri Kaushal Vikas Yojana (PMKVY), National Skill Development Corporation.

[9] https: //sprf. in/vocational - education - in - the - nep - 2020
- opportunities
and
challenges/\#: $\quad \sim$ :
text $=$ The $\% 20$ NEP $\% 202020 \% 20$ is $\% 20$ a,
on $\% 20$ education $\% 20$ over\%20the $\% 20$ years. 